\title{
Relative impacts of land use and climate change on summer precipitation in the Netherlands
}

\author{
Emma Daniels $^{1}$, Geert Lenderink ${ }^{2}$, Ronald Hutjes ${ }^{1}$, and Albert Holtslag ${ }^{1}$ \\ ${ }^{1}$ Wageningen University, Droevendaalsesteeg 3, 6708 PB Wageningen, the Netherlands \\ ${ }^{2}$ KNMI, Utrechtseweg 297, 3731 GA De Bilt, the Netherlands \\ Correspondence to: Emma Daniels (emmadamme@gmail.com) \\ Received: 25 March 2016 - Published in Hydrol. Earth Syst. Sci. Discuss.: 6 April 2016 \\ Revised: 14 September 2016 - Accepted: 15 September 2016 - Published: 11 October 2016
}

\begin{abstract}
The effects of historic and future land use on precipitation in the Netherlands are investigated on 18 summer days with similar meteorological conditions. The days are selected with a circulation type classification and a clustering procedure to obtain a homogenous set of days that is expected to favor land impacts. Changes in precipitation are investigated in relation to the present-day climate and land use, and from the perspective of future climate and land use. To that end, the weather research and forecasting (WRF) model is used with land use maps for 1900, 2000, and 2040. In addition, a temperature perturbation of $+1^{\circ} \mathrm{C}$ assuming constant relative humidity is imposed as a surrogate climate change scenario. Decreases in precipitation of, respectively, $3-5$ and $2-5 \%$ are simulated following conversion of historic to present, and present to future, land use. The temperature perturbation under present land use conditions increases precipitation amounts by on average $7-8 \%$ and amplifies precipitation intensity. However, when also considering future land use, the increase is reduced to $2-6 \%$ on average, and no intensification of extreme precipitation is simulated. In all, the simulated effects of land use changes on precipitation in summer are smaller than the effects of climate change, but are not negligible.
\end{abstract}

\section{Introduction}

Humans can exert influence on precipitation through modifications in land use (Mahmood et al., 2014; Kalnay and Cai, 2003) next to other anthropogenic forcings such as climate change (Zhang et al., 2007). Currently, land conversion takes place at a rapid pace, and this will likely continue in the fu- ture (Mahmood et al., 2010; Angel et al., 2011). Therefore, this type of human influence on the climate system will continue, and will probably become more significant in the coming decades (Pielke et al., 2007; Mahmood et al., 2010).

In the Netherlands, the most important land cover changes in the last century were the conversion of large heather areas into agricultural land or grassland, and expansion of urban areas (Feranec et al., 2010; Verburg et al., 2004). In addition, almost $1650 \mathrm{~km}^{2}$ of land was reclaimed from the sea in the former Zuiderzee, now called Lake Yssel (Hoeksema, 2007). Urban areas have increased from about $2 \%$ in 1900 to $13 \%$ in 2000 , and are projected to further increase to $24 \%$ in 2040 (Dekkers et al., 2012). Precipitation in the Netherlands has increased by about $25 \%$ over the last century, especially along the West coast (Buishand et al., 2013). The increase in sea surface temperatures and changes in circulation seem to be the major causes of this increase (Attema et al., 2014; van Haren et al., 2013). In addition, there is some evidence that urbanization plays a role (Daniels et al., 2015b).

In contrast to the above, an earlier study using a model to investigate land surface changes in the Netherlands in spring found that precipitation is in fact reduced after expansion of urban areas (Daniels et al., 2014). That study also tested the sensitivity of precipitation to soil moisture and found a positive feedback; that is, wet (dry) soils increase (decrease) the amount of precipitation. The reduction of precipitation after urban expansion was dominated by the model's response to reduced moisture, overruling the enhanced triggering of precipitation by boundary layer processes. However, only a 4day case study was investigated and questions can therefore be raised with respect to the climatological representability of the results. In addition, the simulated land use changes 
were conceptual, rather than realistic, and only focused on changes in urban extent, ignoring the expansion of agricultural areas for example.

The present study aims to improve on both aspects, by (1) sampling a larger set of meteorological cases, and (2) evaluating the effects of more realistic land cover changes. Our main interest is the precipitation response to the altered land surface and the physical processes underlying this response. We investigate this response in the summer season. The summer months typically have a larger shower activity, connected to unstable conditions. This relatively intense type of precipitation, arising from (deep) cumulus convection, is expected to be most influenced by land surface changes (Pielke et al., 2007; Cotton and Pielke, 2007) and is typically expected to increase under climate change (Fischer et al., 2014). Also, the largest impact of urban areas on precipitation along the Dutch West coast was found in summer (Daniels et al., 2015b).

The current study also aims to put the effects of historic and future land use changes on precipitation in the perspective of climate change. This will be done by imposing an increase in overall temperatures as a surrogate climate change scenario (Schar et al., 1996). On a global scale, climate change is expected to increase both mean and extreme precipitation in response to an intensification of the hydrological cycle (Huntington, 2006; Wu et al., 2013). Here, the precipitation response to land use changes in the Netherlands, and climate change, is investigated for multiple summer days. The selection procedure for the investigated events and the model setup will be described in the next section, followed by the results, discussion, and conclusions.

\section{Data and methods}

\subsection{Case selection}

Selection of days to use as case studies is conducted with the help of a circulation type classification, similar to Daniels et al. (2015a). We make use of the nine-type JenkinsonCollison types (JCT) classification scheme. This method was developed by Jenkinson and Collison (1977) and is intended to provide an objective scheme that acceptably reproduces the subjective Lamb weather types (Jones et al., 1993; Lamb, 1950). The classification has eight weather types (WTs) representative of the prevailing wind direction $(\mathrm{W}, \mathrm{NW}, \mathrm{N}, \mathrm{NE}$, $\mathrm{E}, \mathrm{SE}, \mathrm{S}$, and $\mathrm{SW}$, where $\mathrm{W}=1$, etc.) and one that is treated as unclassified (WT9). Computation of the WTs is done using 12:00 UTC MSLP data from ERA-Interim (Dee et al., 2011) at 16 points in the area 47.25 to $57.75^{\circ} \mathrm{N}$ and 3 to $12.75^{\circ} \mathrm{E}$ (Fig. 1) with the "cost733class" software (Philipp et al., 2010, 2014).

Previous work has shown that the downwind effects of urban areas on precipitation in the Netherlands are largest under WT9 (Daniels et al., 2015b). Under the light, unclassi- fiable, flow that occurs in this weather type, the atmosphere seems to be most susceptible to the land surface. All summer (JJA) days in the period 2000-2010 are classified with the JCT scheme, but only days with WT9 and more than $1 \mathrm{~mm}$ of precipitation at one station or more are used for further selection. The remaining 215 days are grouped using a statistically objective $k$-means clustering procedure (Hartigan and Wong, 1979) in $\mathrm{R}$ (Core Team, 2013). The $k$-means clustering partitions $n$ observations into $k$ clusters, in which each observation belongs to the cluster with the nearest mean in a principle component space. Clustering is done to obtain a homogenous set of days with similar meteorological conditions. The similarity of the cases should result in comparable results and enable generalization of conclusions.

Seven parameters are used in the clustering procedure: (1) mean precipitation; (2) total column water; (3) vertical velocity at $700 \mathrm{hPa}$; (4) horizontal wind speed at $700 \mathrm{hPa}$; (5) $K$-index; (6) land-sea temperature difference; and (7) a measure of the distribution and "patchiness" of precipitation, computed as the difference between maximum precipitation and the 85th percentile. Parameters 2, 3, 4, and 5 are derived from 12:00 UTC ERA-Interim data averaged over the center of the Netherlands ( 4.75 to $5.75^{\circ} \mathrm{E}$ and 51.75 to $52.25^{\circ} \mathrm{N}$, Fig. 1). Parameter 6 is derived from ERA-Interim data as the difference between the $2 \mathrm{~m}$ temperature over this land area and sea surface temperature (SST) averaged over a nearby ocean area of similar size $\left(3-4^{\circ} \mathrm{E}\right.$ and 52.25 $52.75^{\circ}$ N, Fig. 1). Parameter 1 and 7 are computed over the whole of the Netherlands using daily precipitation data collected at 08:00 UTC from about 320 stations. The $K$-index (George, 1960) is a linear combination of temperature $(T)$ and dewpoint $(\mathrm{Td})$ at various levels $(T 850-T 500+\mathrm{Td} 850$ $-(T 700-\mathrm{Td} 700))$ and is a measure of the convection used to forecast air mass thunderstorms. The parameter values are normalized and scaled by subtracting the mean and dividing by the standard deviation, before being used in the clustering algorithm.

The $k$-means clustering algorithm was set to use 12 clusters, repeated 1000 times, and the best, stable, solution is used. A cluster with higher than mean precipitation was selected (see Fig. 2), since sufficient precipitation is needed to investigate the response to alternative land use maps. Total column water is about average in the selected cluster, while it has the most negative vertical velocity (omega), of about $0.3 \mathrm{~Pa} \mathrm{~s}^{-1}$. Since omega is positive with increasing pressure, this means the largest upward speeds are selected. A large upward vertical velocity is associated with strong hourly precipitation and convective showers (Loriaux et al., 2013). Low wind speed was found to be favorable for detection of urban effects in the Netherlands (Daniels et al., 2015b) and is therefore desirable. The average $K$-index in the selected cluster is over 20, which is the average threshold for likelihood of thunderstorms. The land-sea temperature difference is amongst the lowest. High SST is known to cause enhanced precipitation (in the coastal area), mainly in summer (Lenderink et al., 


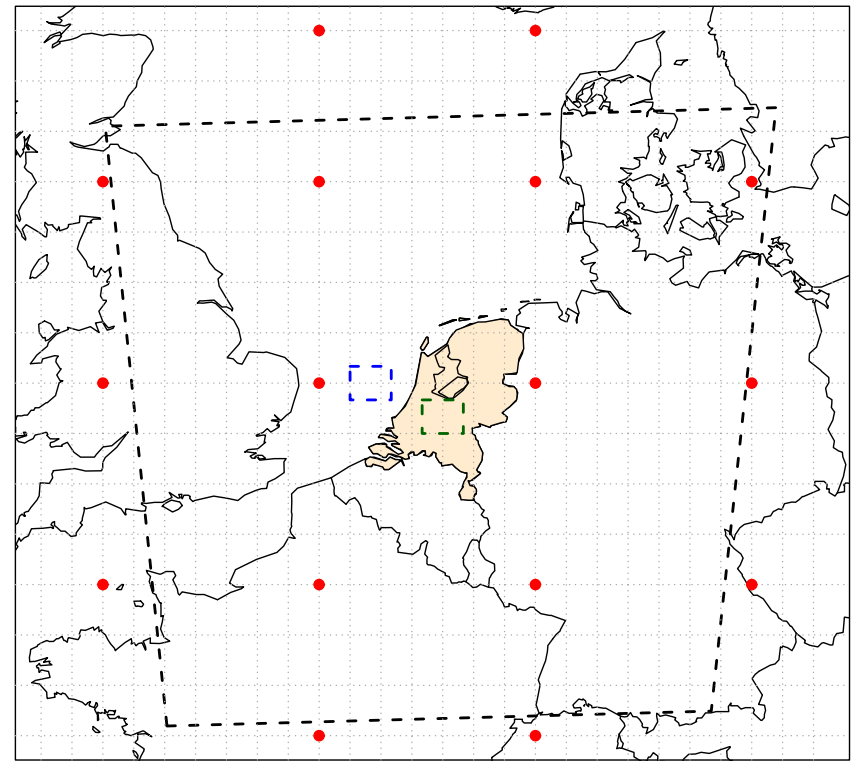

Figure 1. Map of part of Europe showing the 16 (red) points used in the circulation type classification, the WRF model domain (black), and the land (green) and sea (blue) area used for averaging in the selection procedure.

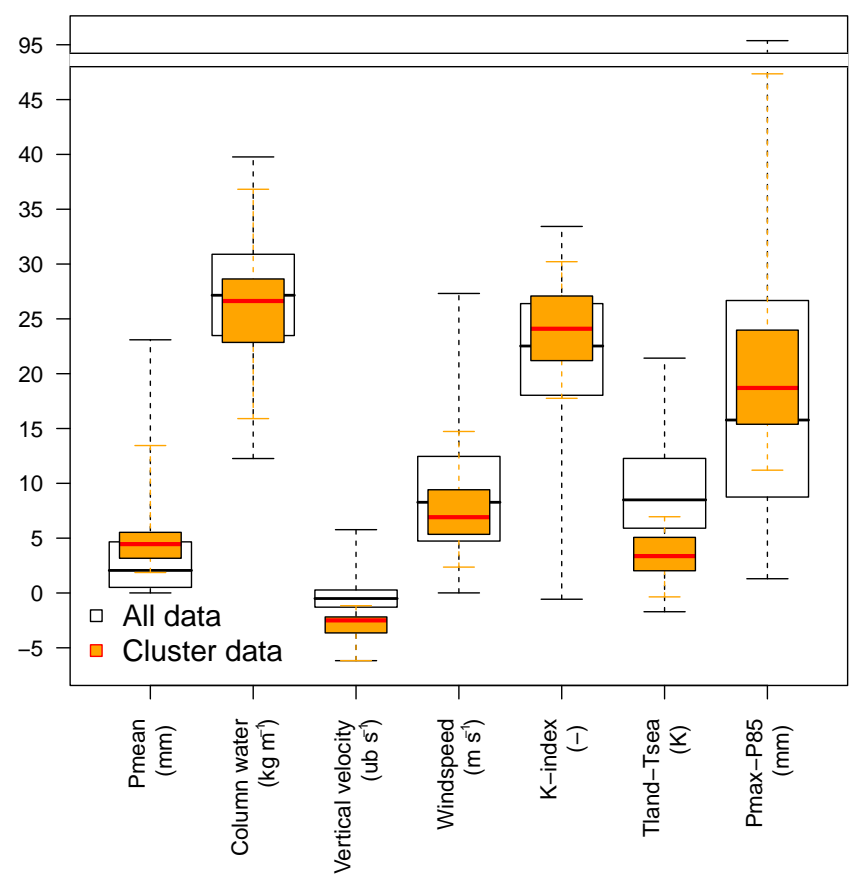

Figure 2. Boxplots of the seven parameters used in the procedure to select days to simulate with the WRF model. Boxes of the days included in the selected cluster are given in orange and boxes of all summer days classified as WT 9 in the period 2000-2010 are given in white.

2009). This could interfere with our land use experiments and is therefore not sought. Finally, the selected cluster has quite patchy precipitation, indicative of convective conditions as desired. The selected cluster consists of 19 days (see Fig. 6 for the dates), of which 18 will be averaged on an hourly basis for many of the analyses presented in the results section.

\subsection{Model setup}

We use the non-hydrostatic Advanced Research WRF model (ARW, version 3.4.1) (Skamarock et al., 2008) on a single domain of $1000 \times 1000 \mathrm{~km}$ (see Fig. 1). The model has a horizontal grid spacing of $2.5 \mathrm{~km}$ and the vertical grid contains 40 sigma levels. Atmospheric and surface boundary conditions are obtained from ERA-Interim every $6 \mathrm{~h}$. Model output is stored and analyzed on an hourly basis. The model is run for $48 \mathrm{~h}$, including $12 \mathrm{~h}$ of spin-up from 12:00 to 00:00 UTC the previous day, $24 \mathrm{~h}$ of simulation on the chosen day, and 12 additional hours to be able to compare it to both radar data (00:00-00:00 UTC) and station data (08:00-08:00 UTC).

Following earlier studies with WRF in the Netherlands (e.g., Steeneveld et al., 2011; Daniels et al., 2015a; Theeuwes et al., 2013), we selected the following schemes to represent subgrid processes: the YSU PBL scheme (Hong et al., 2006), the WRF Single-Moment 6-Class Microphysics Scheme (WSM6) (Hong and Lim, 2006), the RRTMG schemes for both longwave and shortwave radiation (Iacono et al., 2008), the Grell 3-D cumulus parameterization scheme (Grell, 1993; Grell and Devenyi, 2002), and the Unified Noah Land Surface Model (Tewari et al., 2004) with the Urban Canopy Model (UCM). The UCM is a single-layer model that has a simplified urban geometry. Included in the UCM are shadowing from buildings, reflection of shortwave and longwave radiation, the wind profile in the canopy layer, and multilayer heat transfer equations for roof, wall, and road surfaces (Kusaka et al., 2001; Kusaka and Kimura, 2004).

Where possible within the model domain, the European Corine land use map (EEA, 2002) was used, supplemented with a high-resolution map for the Netherlands. Corine is not available over the UK, so there the standard USGS map at $30^{\prime}$ resolution available within WRF is used. Reclassification of the Corine land use map is done following Pineda et al. (2004), but intertidal flats are classified as water instead of herbaceous wetlands. Three high-resolution maps were used for the Netherlands: HGN1900 (Kramer et al., 2010), LGN4 (Hazeu et al., 2011; Wit, 2003; Hazeu et al., 2010), and GE2040 (Dekkers et al., 2012), representing land use in 1900, 2000, and 2040, respectively (see Fig. 3). The future map is based on the Dutch Global Economy scenario (CPB et al., 2006), a national scenario consistent with the SRES A2 scenario. The SRES scenarios have been replaced by Representative Concentration Pathways (RCPs) and Shared Socioeconomic Pathways (SSPs). The SRES A2 scenario is most like SSP 3 and between RCP 6.0 and 8.5 in carbon emissions. Reclassification of the Dutch land use maps is done as specified in Table 1. GE2040 unfortunately did not distinguish between different dry nature classes, so the differentia- 


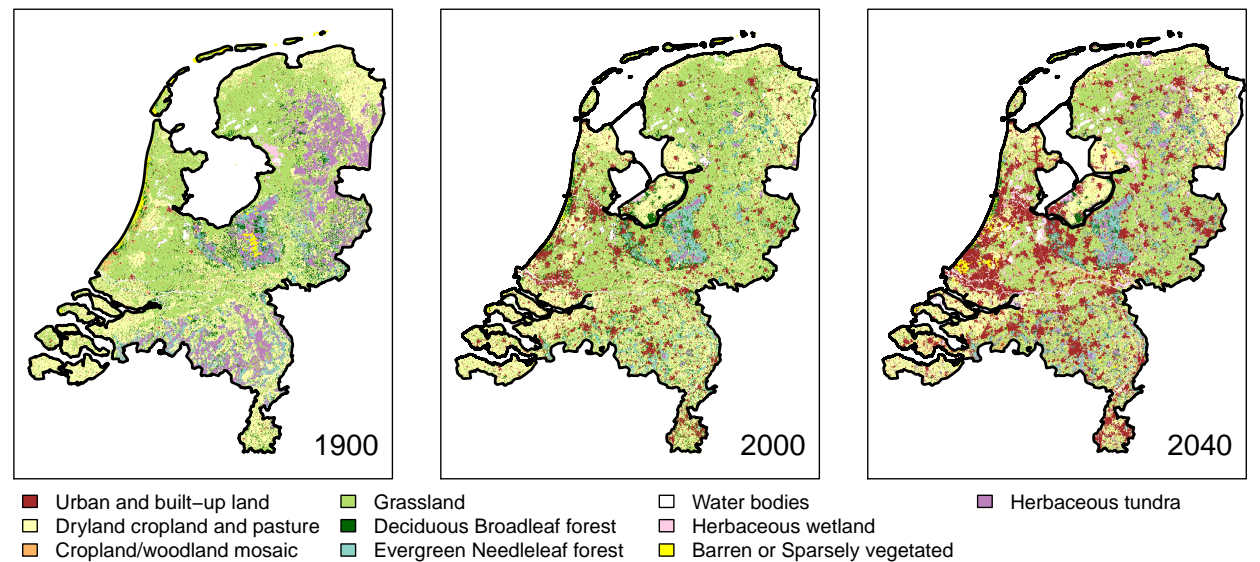

Figure 3. Dutch land use maps for 1900, 2000, and 2040 based on HGN1900, LGN4, and GE2040, respectively.

Table 1. USGS land use category descriptions and parameter settings used in WRF, with the national land use map (HGN, LGN, and GE2040) classes that are reclassified as such.

\begin{tabular}{|c|c|c|c|c|c|c|c|c|}
\hline $\begin{array}{l}\text { USGS land } \\
\text { use category }\end{array}$ & $\begin{array}{l}\text { Land use } \\
\text { description }\end{array}$ & $\begin{array}{l}z_{0} \\
(\mathrm{~m})\end{array}$ & $\begin{array}{l}\text { Albedo } \\
(-)\end{array}$ & $\begin{array}{l}\text { Green vegetation } \\
\text { fraction }(\%)\end{array}$ & $\begin{array}{l}\text { Leaf area } \\
\text { index }\end{array}$ & $\begin{array}{l}\text { Emissivity } \\
(\%)\end{array}$ & $\begin{array}{l}\text { HGN/LGN class } \\
\text { description }\end{array}$ & $\begin{array}{l}\text { GE2040 class } \\
\text { description }\end{array}$ \\
\hline 1 & Urban and built-up land & 0.5 & 0.15 & 0.1 & 1 & 0.88 & Buildings and roads & $\begin{array}{l}\text { Urban area, commercial/ } \\
\text { industrial, seaport, } \\
\text { building lot, } \\
\text { infrastructure }\end{array}$ \\
\hline 2 & Dryland cropland and pasture & 0.15 & 0.17 & 0.8 & 5.68 & 0.985 & Crops and bare soil & Arable land \\
\hline 6 & Cropland/woodland mosaic & 0.2 & 0.16 & 0.8 & 4 & 0.985 & Other & $\begin{array}{l}\text { Recreation - single day, } \\
\text { recreation - stay, } \\
\text { perennial crops }\end{array}$ \\
\hline 7 & Grassland & 0.12 & 0.19 & 0.8 & 2.9 & 0.96 & Grassland & Grassland \\
\hline 11 & Deciduous broadleaf forest & 0.5 & 0.16 & 0.8 & 3.31 & 0.93 & Deciduous forest & Nature - dry \\
\hline 14 & Evergreen needle leaf & 0.5 & 0.12 & 0.7 & 6.4 & 0.95 & Coniferous forest & Nature - dry \\
\hline 16 & Water bodies & 0.0001 & 0.08 & 0 & 0.01 & 0.98 & Water & Water \\
\hline 17 & Herbaceous wetland & 0.2 & 0.14 & 0.6 & 5.65 & 0.95 & Reed swamps & Nature - wet \\
\hline 19 & Barren or sparsely vegetated & 0.01 & 0.38 & 0.01 & 0.75 & 0.9 & Drifting sands and sandbanks & $\begin{array}{l}\text { Greenhouse horticulture, } \\
\text { nature - dry }\end{array}$ \\
\hline 20 & Herbaceous tundra & 0.1 & 0.15 & 0.6 & 3.35 & 0.92 & Heath land and raised bogs & Nature - dry \\
\hline
\end{tabular}

tion was copied from the LGN map. Therefore, all dry nature in GE2040 was first classified as herbaceous tundra. Next the newly classified herbaceous tundra was reclassified to barren or sparsely vegetated areas, evergreen needle leaf, and deciduous broadleaf forest when it overlapped with the areas classified as such in the LGN map.

\subsection{Model simulations}

Three model simulations, HIS, REF, and FUT, are done with the land use maps of, respectively, 1900, 2000, and 2040 in the Netherlands. These simulations have exactly the same boundary conditions. In 1900 the creation of land in Lake Yssel had not yet taken place. To test the effect of this conversion separately from the changes in land use, an additional simulation with the historic land use map was done, this time with the current land extent (similar to that in REF). All previously non-existent land is assumed to be covered with grassland (the most common land cover class). This simulation is referred to as HIS+Ys.
Furthermore, to be able to put the land cover changes in the perspective of climate change, simulations with the present and future land use maps and a temperature perturbation of $+1^{\circ} \mathrm{C}$ are conducted. These will be referred to as REF +1 and FUT +1 . The global surface temperature is predicted to increase by at least $1{ }^{\circ} \mathrm{C}$ under all concentration pathways by 2050 (IPCC, 2013). The surrogate climate change scenario is applied to the initial land and atmospheric conditions of the simulations, as well as to the driving sea surface temperature following the methodology by Attema et al. (2014), who suggest a vertically uniform temperature perturbation is appropriate at mid-latitudes. The relative humidity is unchanged in these simulations, which implies an absolute surface humidity increase of $6-7 \%$.

Urban areas outside of the Netherlands are removed in the historic, and expanded in the future, land cover scenarios, in the same way as in Daniels et al. (2014). Angel et al. (2011)'s projections of urban land cover are used to determine the level of expansion. Across the globe, urban land cover has increased due to people migrating to urban areas 
and because the population density within cities decreased (Marshall, 2007). Within Europe a population density decline rate of $2 \%$ per annum was reached between 1990 and 2000 (Angel et al., 2011). We assume a conservative increase with a decline rate of $1 \%$ for the future. Urban areas are therefore less than doubled in our simulations, consistent with Angel's projection for Europe and Japan in 2050 with an annual density decline of $1 \%$.

\subsection{Precipitation data}

In the Netherlands, measurements of precipitation are available from the national meteorological institute (KNMI). Gauge measurements are available on a daily basis (08:0008:00 UTC) at about 320 stations. Gridded observations of precipitation are available at a $2.4 \mathrm{~km}$ resolution on an hourly basis from (bias-)corrected radar data (Overeem et al., 2009). Modeled precipitation amounts are best compared with radar data, because of the similarity in resolution and spatial extent. Unfortunately for 4 of the 19 selected cases there are no radar data available, so some averages shown in the results sections consist of fewer cases.

\section{Results}

The focus of this paper is on the sensitivity of precipitation to changes in land surface conditions in historical and future perspectives. The precipitation response to the perturbations in the experiments will be described in the next section. To clarify these responses, the section after that focusses on the (differences in) atmospheric conditions and processes leading to the formation of precipitation.

In general, the WRF model overestimates precipitation amounts compared to both station and radar data (Fig. 4). The days marked with red markers only have station data, and no radar data are available. There is 1 day where precipitation amounts are grossly overestimated, namely for 30 June 2003. This day is marked with an open dot in the scatterplot. This is the only day in the selection that has easterly winds, and the poor model performance could therefore be related to the chosen position of the domain. This day was excluded from further analysis, so only 18 days are used further on in this paper. The average wind direction on the other days is southwest, like the year-round dominant wind direction in the Netherlands.

The performance of the model in representing spatial precipitation patterns is reasonable overall, but shows quite patchy results (Fig. 5). The precipitation pattern of 29 July 2000 for example is well represented by the model. This day is denoted by a triangle in Fig. 4. As an example in which the model does not represent the spatial precipitation pattern well, the precipitation pattern of 22 July 2007 is given. This day is denoted by a square in Fig. 4. Compared to the previous example, this day is more accurately mod-

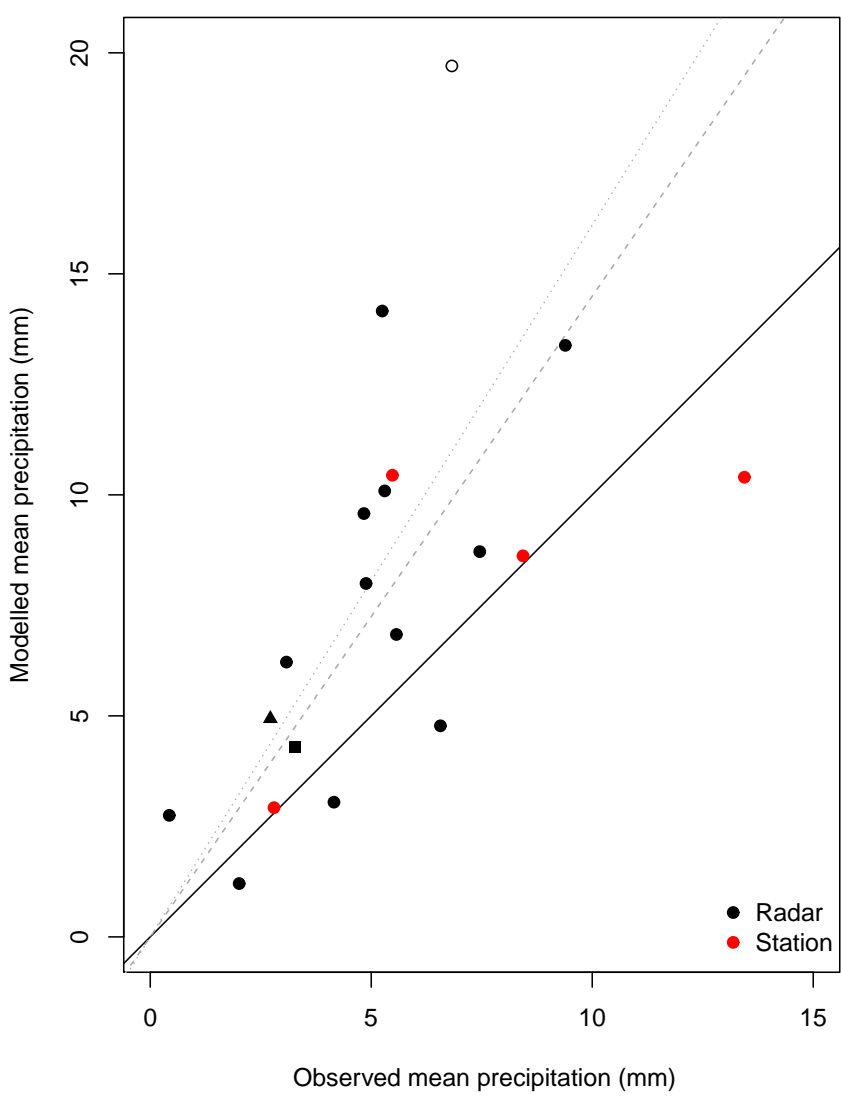

Figure 4. Scatterplot of observed and modeled daily mean precipitation ( $\mathrm{mm} \mathrm{day}^{-1}$ ) by radar (black, 00:00-00:00 UTC) and at stations (red, 08:00-08:00 UTC) over the Netherlands. The dotted and dashed lines give a linear regression between precipitation modeled and observed by radar, respectively, including and excluding the day indicated with an open dot (30 June 2003). The days with a square (22 July 2007) and triangle (29 July 2000) are illustrated spatially in Fig. 5. The solid $1: 1$ line represents a perfect correlation.

eled in terms of amounts, but the modeled spatial distribution is quite distant from that observed. The average spatial distribution of all 18 cases overestimates the amount of precipitation compared to observed station data by almost $50 \%$. Nevertheless, the model seems to capture the relatively high precipitation amounts in the center of the country and lower rainfall amounts in the northern parts.

The daily evolution of precipitation in observations and in the model is given in Fig. 8, which will be discussed more thoroughly in the next section. Compared to radar data, the phasing of all model runs is $3 \mathrm{~h}$ too early in simulating the intensification of precipitation, and the modeled precipitation peak is $2 \mathrm{~h}$ too early. In addition, the average precipitation intensity is often higher than in observations. The separation of the model and observations in the evening is found on only 2 days and is therefore not a generic feature. The comparison between the radar data and the modeled amounts in Fig. 8 is not entirely consistent, however, since the averages are made 

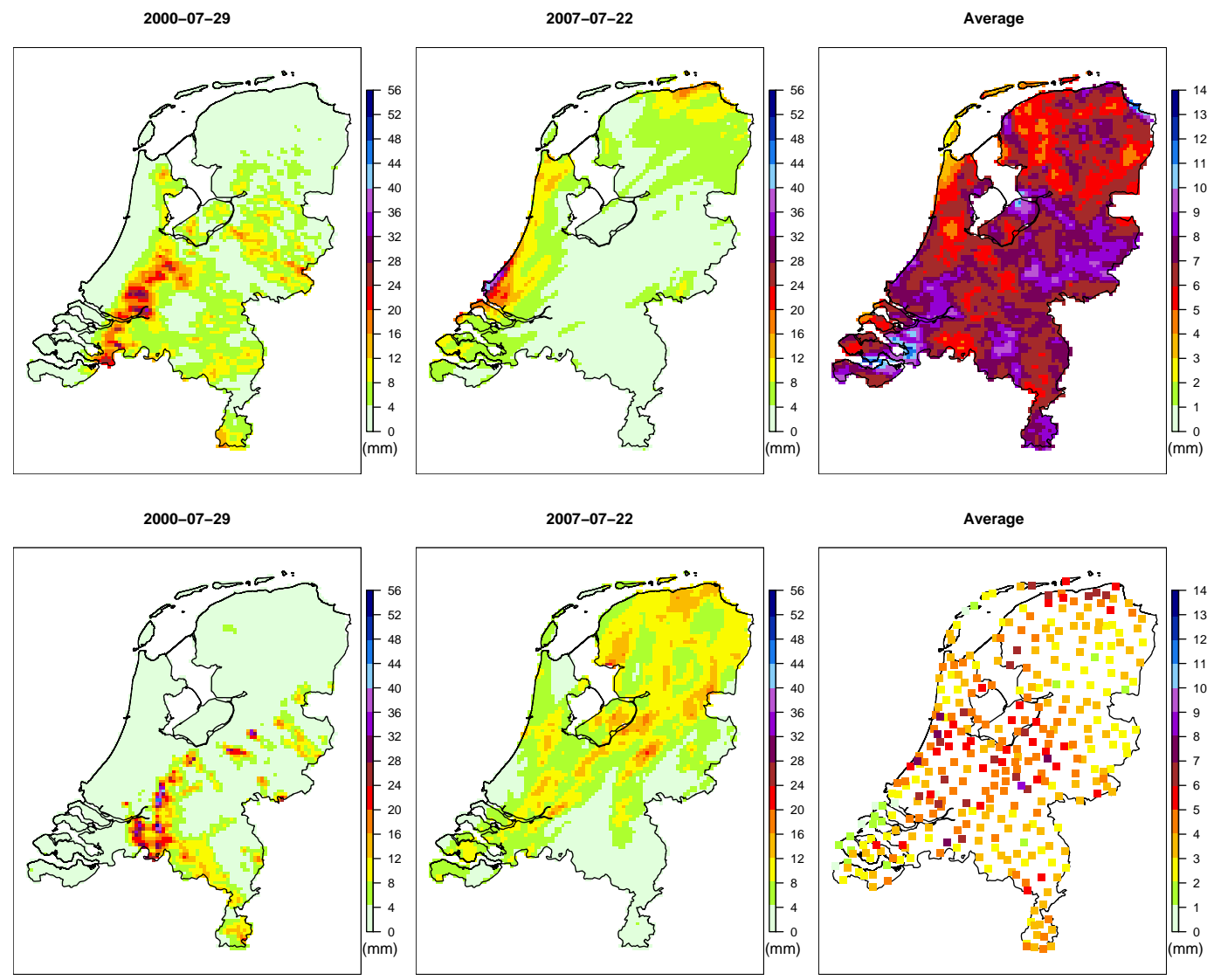

Figure 5. Daily mean precipitation $\left(\mathrm{mm} \mathrm{day}^{-1}\right.$ ) simulated by the model (top) and observed (bottom) on (from left to right) $29 \mathrm{July} 2000$ and 22 July 2007 (00:00 to 00:00 UTC), and averaged (08:00 to 08:00 UTC) over the 18 selected cases.

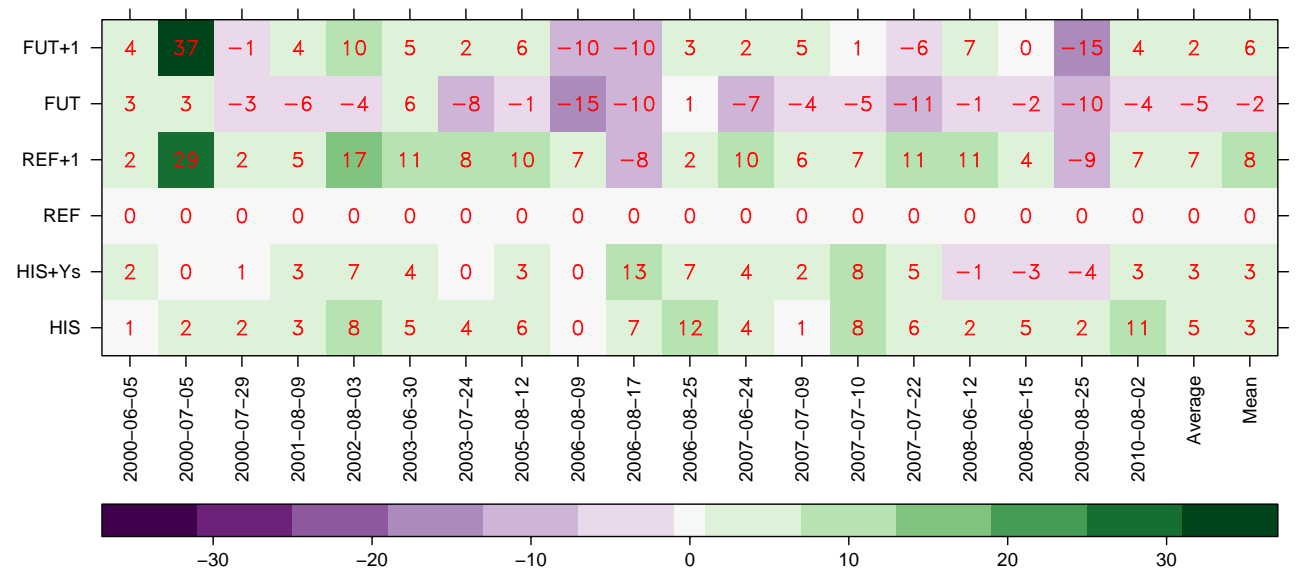

Figure 6. Relative precipitation difference (\%) in each of the cases for all experiments compared to REF. Here the average is directly calculated over the 18 selected cases and the mean is calculated using the mean spatial differences as given in Fig. 7.

over a different number of cases (14 vs. 18 , respectively). Repeating the analysis with the lower number of cases leads to the same results.

\subsection{Precipitation response}

Despite the fact that we select days with similar atmospheric conditions, the response of precipitation to the land use and climate perturbations is not uniform and varies strongly be- 

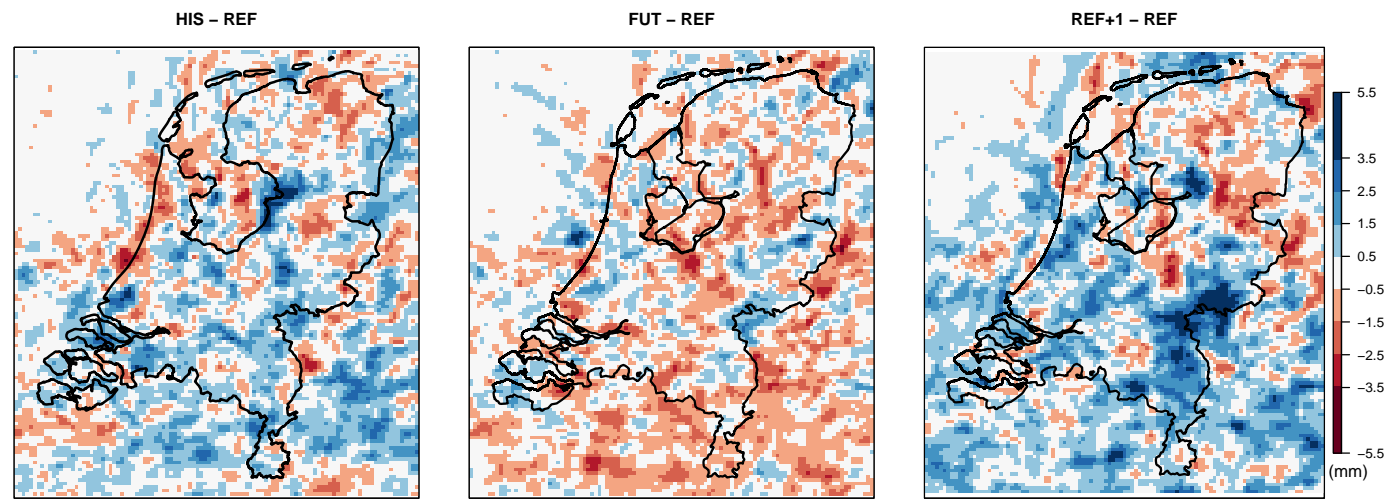

Figure 7. Spatial precipitation differences $\left(\mathrm{mm} \mathrm{day}^{-1}\right)$ between the HIS, REF+1, and FUT experiments and the reference experiment.

tween the different cases. In Fig. 6 the relative difference of precipitation between the land cover/temperature scenarios and REF is given for each of the 19 cases. The average precipitation difference given here is calculated over the 18 cases (excluding the 30 June 2003 case) by averaging the relative change per case. The mean precipitation difference is, on the other hand, directly calculated from the averaged precipitation amount of the 18 cases as given in Fig. 7. Although the strength and sometimes the sign of the response differs between the days in every simulation, a generic picture of a decrease in precipitation appears as a response to changes in land use. From historic to present, and from present to future, land use, the decrease is about $3-5$ and $2-5 \%$, respectively.

One of the averaging methods shows a difference between HIS and HIS+Ys, suggesting that the creation of land in Lake Yssel caused a moderate reduction of precipitation in the last century. The other method gives the same response for both HIS scenarios, suggesting the creation of land in Lake Yssel did not influence the total precipitation response. Either way, the model simulates a reduction of precipitation between HIS(+Ys) and REF. Similarly, the difference between FUT and REF is negative, so a reduction of precipitation is simulated by the model after incorporation of future land use.

On average, the spatial differences between the simulations are quite patchy (Fig. 7). All simulations show small areas of enhancement as well as areas of reduction in precipitation. The reduction in FUT is seen over large parts of the Netherlands. Urbanization mainly takes place along the West coast, where the reduction of precipitation seems to be moderate. The relatively small reduction might be caused by the downwind enhancement of precipitation by urban areas, though the patchiness in the rest of the country does not seem supportive of this hypothesis. In the HIS simulation, the largest enhancement is located on the eastern side of Lake Yssel. This increase is not visible in the HIS+Ys simulation, so it might be caused by the relatively high SST and evaporation over Lake Yssel itself and subsequent higher moisture content of the air when it reaches the coast. The enhancement of precipitation in REF+1 and FUT+1 is most pronounced along the southeastern border of the country. The relatively large spatial changes shown here average out to the relative changes given before in the order of $2-8 \%$, which is only $0.1-0.6 \mathrm{~mm}$. So the average changes between the runs are much smaller than the patchy spatial differences seen here.

It is interesting to see whether the precipitation response to the perturbations happens equally throughout the day, or whether it occurs during a specific moment. In the mean daily evolution of precipitation, the differences between HIS $(+\mathrm{Ys})$ and REF are hardly distinguishable (Fig. 8). The differences between FUT and REF manifest themselves in the middle of the day when the intensity of precipitation is lower in FUT. This reduction of precipitation is also seen in FUT +1 and must be caused by land use changes, like the expansion of urban areas. The most pronounced temporal differences are visible in the temperature perturbation experiments: $\mathrm{REF}+1$ and FUT +1 . The differences are most evident in the early morning between 02:00 and 08:00 UTC. This difference is not significant as the divergence is mainly caused by the precipitation enhancement on 2000-07-05, the day with the largest response to the temperature perturbations. So the only systematic differences between REF and other simulations are seen in FUT and FUT+1 in the middle of the day.

The REF+1 and FUT+1 surrogate climate change experiments are conducted to allow a comparison between changes in precipitation due to land use changes and due to climate change. In our simulations, precipitation in the Netherlands increases in the temperature scenarios. The 7-8\% rainfall increase in REF+1 (Fig. 6) is close to the increase of about $7 \% \mathrm{~K}^{-1}$ in near surface humidity that follows from the Clausius-Clapeyron equation (O'Gorman and Muller, 2010). FUT +1 shows a more moderate increase in precipitation of $2-6 \%$. The increase seems to be offset by the reduction in precipitation from the expected land use change that is obtained in FUT. Interestingly, it appears that the precipitation response to land use change and to the climate perturbation can be added linearly. So the mean and average values in Fig. 6 in REF+1 of, respectively, 8 and $7 \%$ are reduced with the mean and average values in FUT, of -2 and $-5 \%$, re- 


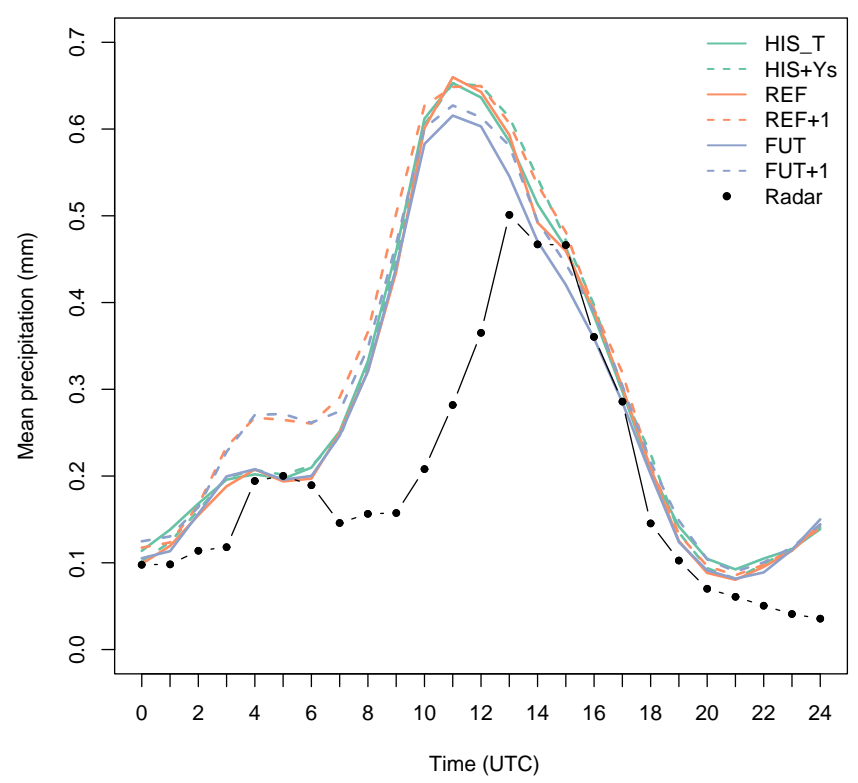

Figure 8. Diurnal cycle of mean precipitation $\left(\mathrm{mm} \mathrm{h}^{-1}\right)$ over the Netherlands in the different experiments (averaged over 18 cases) and given by radar data (averaged over 14 cases).

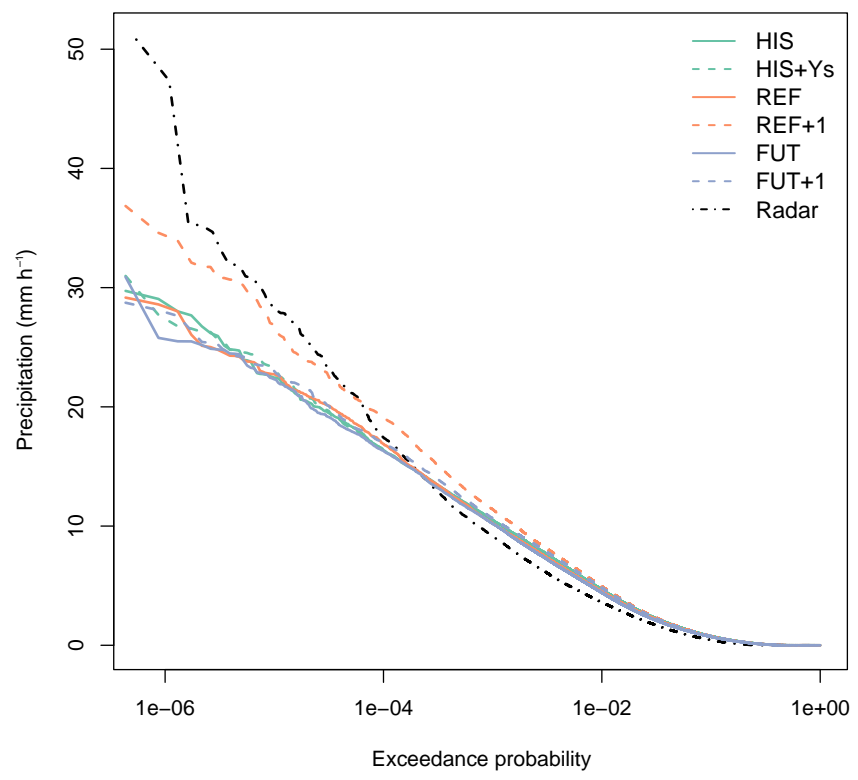

Figure 9. Distribution of hourly precipitation $\left(\mathrm{mm} \mathrm{h}^{-1}\right)$ for each of the experiments and radar data, averaged over the 14 days that have radar data available.

spectively, to attain the mean and average values in FUT +1 , of 6 and $2 \%$, respectively.

The distribution of precipitation is not well represented by the model, but is consistent among the scenarios (Fig. 9). The extremes of precipitation are very similar in all of the experiments, except for REF+1. The REF+1 simulation reveals a considerable increase in precipitation extremes. In the tail of

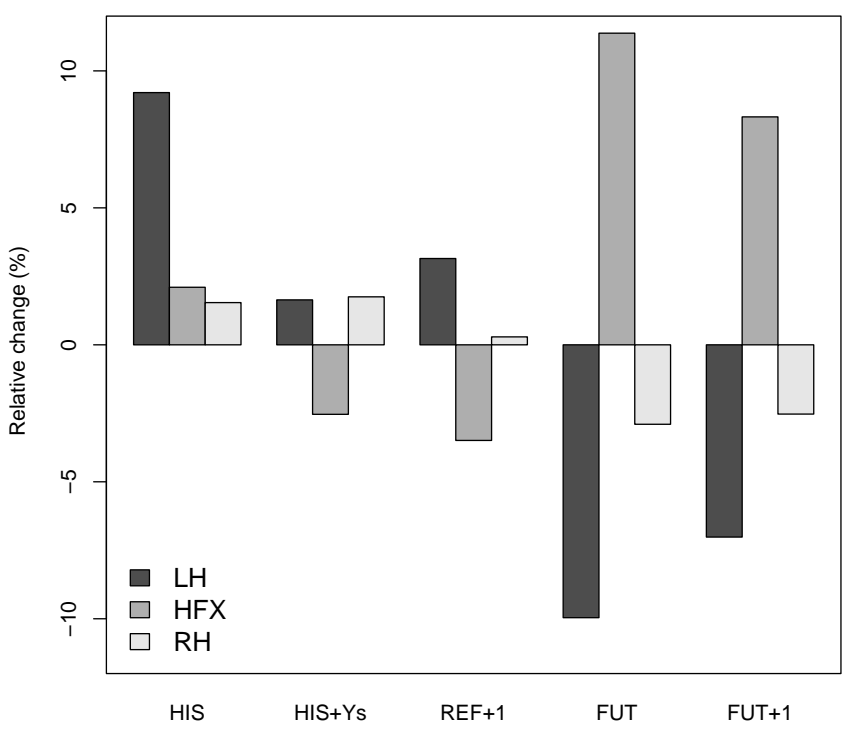

Figure 10. Mean relative change (\%) over the Netherlands in latent heat flux (LH), sensible heat flux (HFX), and relative humidity (RH) in each of the experiments in comparison to REF.

the distribution the difference with REF is more than $20 \%$. For more moderate extremes $(>15 \mathrm{~mm})$ the difference between REF+1 and REF is about $10 \%$. Although mean precipitation increases in FUT+1, the distribution remains similar to REF. Apparently extreme precipitation is in this case influenced more by land use changes than mean precipitation. The spatial distribution of the enhanced precipitation is similar to the pattern of mean precipitation; in other words, there is more rain in the same locations. Overall, what can be inferred is that climate change and future land use change have an equal, though opposed, effect on extreme precipitation. The atmospheric conditions and relatively little (deep) convection in FUT +1 seem to play a role in the differences between the simulations.

\subsection{Surface and atmospheric conditions}

To understand the differences between the various simulations, this section focusses on surface and atmospheric conditions. We first consider changes in the latent and sensible heat flux and changes in $2 \mathrm{~m}$ relative humidity. In HIS both a higher latent and sensible heat flux are seen in comparison to REF and to HIS+Ys (Fig. 10 and Table 2). This is largely caused by the inclusion of part of Lake Yssel in the averaging, as the high lake temperature and low albedo cause both fluxes to be enhanced. In HIS+Ys the latent heat flux and relative humidity are somewhat higher than in REF, but the sensible heat flux is lower. Consequently the available moisture in both historical simulations will be higher, and this boosts precipitation amounts. In the FUT simulations the reverse effect happens as moisture is reduced after expansion of urban areas and other land use conversions. 
Table 2. Mean daily (00:00-00:00 UTC) values of latent heat flux (LH), sensible heat (HFX), convective available potential energy (CAPE), precipitation (RAIN), and daytime (06:00-18:00 UTC) values of the percentage of time and area that the planetary boundary layer top is over the level of free convection (PBL > LFC), likewise for lifting condensation level (PBL > LCL), over the Netherlands for the conducted experiments.

\begin{tabular}{llcccccc}
\hline Variable & Unit & HIS & HIS+Ys & REF & REF+1 & FUT & FUT+1 \\
\hline LH & $\mathrm{W} \mathrm{m}^{2}$ & 88.6 & 82.5 & 81.1 & 83.7 & 73.0 & 75.4 \\
HFX & $\mathrm{W} \mathrm{m}^{2}$ & 40.2 & 38.4 & 39.4 & 38.0 & 43.8 & 42.6 \\
CAPE & $\mathrm{J} \mathrm{kg}^{-1}$ & 330.1 & 311.4 & 301.2 & 360.6 & 290.1 & 346.7 \\
PBL $>$ LCL & $\%$ & 54.2 & 54.0 & 52.7 & 52.9 & 51.0 & 51.2 \\
PBL $>$ LFC & $\%$ & 45.3 & 45.0 & 43.7 & 44.0 & 41.7 & 42.1 \\
RAIN & mm day & 7.5 & 7.3 & 7.2 & 7.7 & 6.9 & 7.5 \\
\hline
\end{tabular}

In REF+1 the heat fluxes are not that different from REF. Nevertheless, there is a large precipitation response. The imposed temperature perturbation with constant relative humidity increases the amount of moisture at the time of initialization and the amount that enters the model domain at the boundaries, causing precipitation to change, but fluxes to remain the same. In FUT and FUT+1 a reduction of the latent heat flux is simulated in comparison to REF. Also, in both experiments relative humidity at the surface is lower than in REF. The expansion of urban areas leads to an increase in the sensible heat flux and a decrease in the latent heat flux, since potential evaporation is reduced within urban areas. This decreases overall moisture availability. The surface responses in FUT and FUT+1 look relatively similar, though the precipitation response relative to REF is of opposite sign in the experiments (Fig. 6).

We now focus on the possibility of triggering convection by considering the atmospheric conditions. Figure 11 shows the median of the diurnal cycle of the planetary boundary layer (PBL), lifting condensation level (LCL), level of free convection (LFC), and convective available potential energy (CAPE) calculated at the lowest model level, of the 18 cases in the REF experiment. We show the median because the mean is influenced more by outliers from individual cases. For REF+1, FUT, and FUT+1, the average difference with regards to REF is given for each of these variables. The differences are normalized with respect to the mean values in REF, so a relative increase is given at every time. On average, the PBL increases to about $800 \mathrm{~m}$ during daytime and reaches the LCL at around 09:00 UTC. In the figure, the LFC remains well above the PBL and LCL. In many individual cases, however, the LFC drops to about $800 \mathrm{~m}$ as well, permitting (deep) convection. The LFC reaches its lowest level at 11:00 UTC. This coincides with the time of the highest precipitation intensities in the model (Fig. 8). CAPE increases up to 09:00 UTC, while the LFC decreases and then stabilizes because of the rain and associated temperature and humidity changes. The early onset and intensification of precipitation in the model (Fig. 8) contributes to the small buildup of CAPE and could explain the underestimation of ex- treme precipitation compared to observations (Fig. 9). Also, there are large spatial variations in these variables. Therefore, we computed the fraction of space and time that the PBL is higher than the LCL and LFC, respectively (Table 2). We consider this a measure of the amount of triggering that occurs.

In $\mathrm{REF}+1$ the temperature is higher, while the PBL is quite similar to REF. During daytime there is little difference between REF and REF+1 regarding the LCL and LFC, and approximately the same amount of triggering (PBL higher than LCL/LFC) occurs (Table 2). At night the LCL and LFC are lower in REF+1 than in REF. CAPE is higher throughout the day in REF+1 than in REF, likely due to the enhanced moisture content above the PBL as a result of the imposed climate change scenario. This leads to the simulation of higher precipitation amounts and intensities in REF+1 (Fig. 9). In FUT the large sensible heat flux causes the PBL to grow more during the day and stay higher during the evening than in REF. The relatively large sensible heat flux also affects and raises the LCL and LFC. In comparison to REF, CAPE decreases in FUT from 08:00 UTC onwards when temperatures go up, and relatively little moisture is available. Consequently, less precipitation is simulated.

In FUT+1 a combination of atmospheric processes from FUT and REF+1 can be seen. The LFC remains lower (like in REF+1), while the PBL and LCL are slightly higher (like in FUT). Accordingly, CAPE is higher than in REF at the beginning and end of the day (like in REF+1) and drops early in the day (like in FUT). In FUT+1 in total, precipitation is enhanced by the moisture availability from the boundary conditions imposed through the climate change scenario, but high-intensity precipitation is not simulated because there is little triggering and (deep) convection. Strong precipitation events are caused by convective instability, which is measured by CAPE, and generally occur during daytime. In FUT +1 , CAPE is mainly enhanced during nighttime, not during daytime. The relatively low values of CAPE during daytime likely explain the absence of a response in the tail of the precipitation distribution in FUT (Fig. 9). 

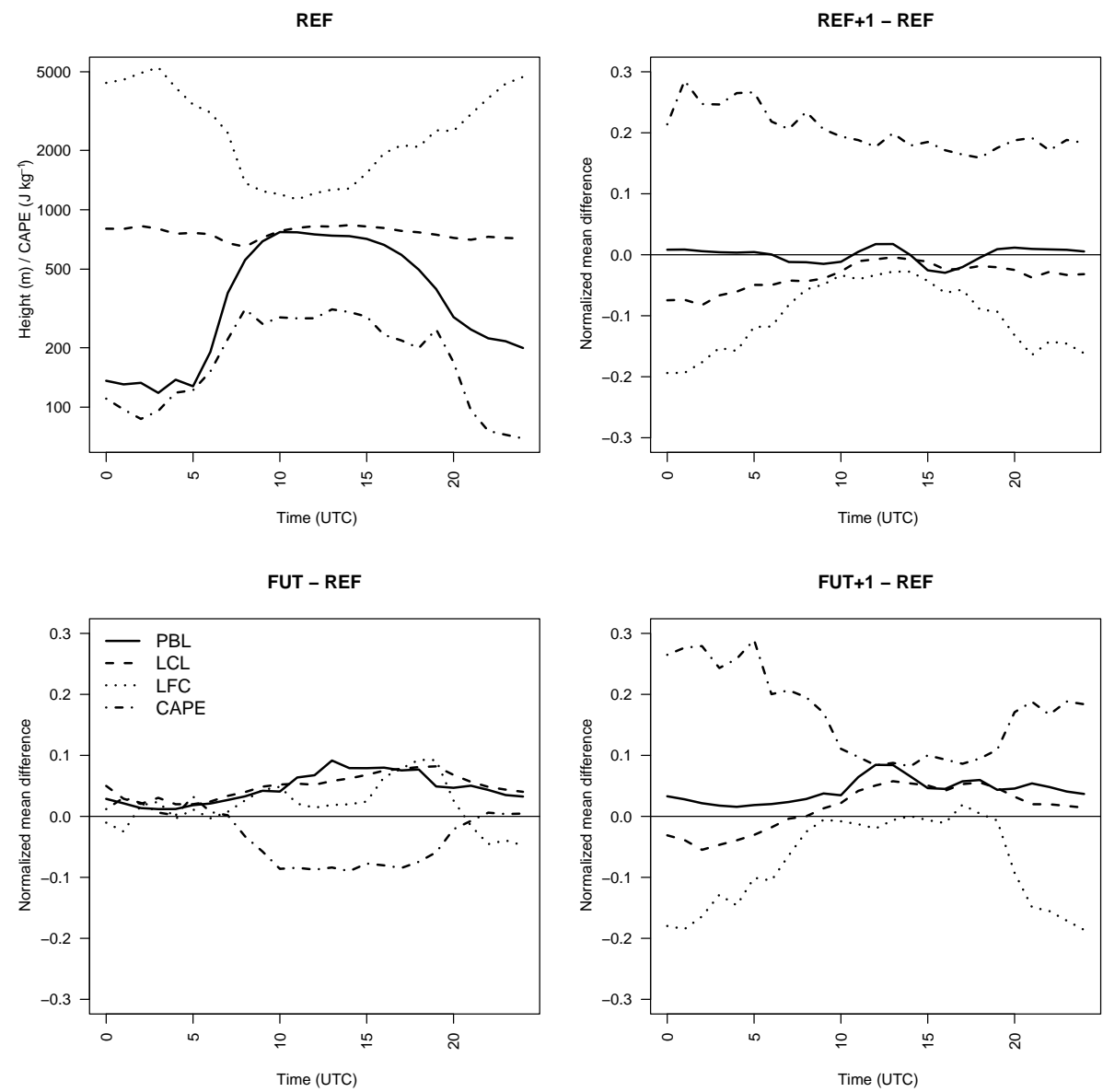

Figure 11. Diurnal cycle of the planetary boundary layer (PBL, solid), lifting condensation level (LCL, dashed), level of free convection (LFC, dotted) (m), and convective available potential energy (CAPE, dash-dotted) $\left(\mathrm{J} \mathrm{kg}^{-1}\right)$ in the reference experiment and normalized mean difference of these variables in the experiments with a temperature perturbation and reference land cover (REF+1), future land cover (FUT), and a temperature perturbation and future land cover $(\mathrm{FUT}+1)$.

\section{Discussion}

Although WRF is a widely used atmospheric model, questions regarding the choice of parameterization schemes and the model's validity for the specific conditions always remain. The sensitivity to different parameterization schemes was not specifically investigated in this study, while this is known to be important (Gallus and Bresch, 2006; Jankov et al., 2005; Rajeevan et al., 2010; Ruiz et al., 2010; Zeng et al., 2012; ter Maat et al., 2013). The chosen YSU PBL scheme is a first-order nonlocal scheme that is widely used under convective conditions (Hu et al., 2010). Sensitivity to initial conditions was checked for some of the cases by starting the runs up to $3 \mathrm{~h}$ earlier or later. This had relatively little effect and WRF seems pretty robust in its predictions, so the sensitivity is small. Previous work (Daniels et al., 2015a) found the largest sensitivity to the initial soil moisture conditions. In the Netherlands those conditions are generally at field capacity due to the frequent rain and high groundwater table and can therefore be expected to have limited influence.
The HIS, REF, and FUT experiments were duplicated without the convection scheme, but this was found to have little effect on precipitation amounts and is therefore not shown. The utilized and presented model design is consequently only one version of reality, of which many more could be simulated.

In this paper our main interest is the response of the model to changes in land use relative to climate change. The model is very capable of simulating temperature (changes), as was shown in Daniels et al. (2015a). Although the model's representation of precipitation is not perfect for the current climate, we believe that the current setup can still be useful for exploring the sensitivities. In addition, the model was used in a slightly different setup for a 4-day case in spring, and comparable results regarding the response of precipitation to increased urban areas were found (Daniels et al., 2015a). A similar reduction in precipitation was also found with the MM5 model for Europe as a whole (Trusilova et al., 2009, 2008), which gives confidence in the results. Trusilova et al. (2009) simulated a $0.2 \mathrm{~mm} \mathrm{day}^{-1}$ reduction in precipitation 
in summer after expansion of urban land by $40 \%$. They also found that the area in which precipitation was altered increased nearly linearly with the urban land increment.

The utilized procedure to select cases for simulation was intended to obtain a homogeneous set of days with similar meteorological conditions that were thought to favor the land surface impact on precipitation. A large spread among responses to land use and temperature scenarios was found between the cases, however, so the intended comparability was not fully accomplished. This could be a model artefact or a realistic response showing how differently the atmosphere reacts to similar conditions, thus showing natural variability. Nevertheless, the majority of cases have a similar sign in their response. By averaging the results we find a more representable response then the response of any single case could be. Our estimates could be biased by the selection procedure that selected cases with rather strong convective activity. Consequently, convection will always be triggered in the selected cases and a potential feedback increasing precipitation through enhanced triggering was excluded. Examples of this feedback can be found in Findell and Eltahir (2003), Santanello et al. (2011), Taylor et al. (2012), and others. The Netherlands is however not located in a region where strong feedbacks of this type are expected (Seneviratne et al., 2006; The GLACE Team et al., 2004) and the influence of changes in climate, SST, or circulation are likely more important (Attema et al., 2014; van Haren et al., 2013). If the selection procedure had been more successful in identifying similar events, we could have made a composite event by averaging the initial and boundary conditions, similar to Mahoney et al. (2012). Their procedure sounds promising, because it could reduce simulation time and provide a more representative response, but the selection of cases to average is apparently not straightforward.

In this study reductions in precipitation from historic to present, as well as from present to future, land use are obtained for selected summer cases in the Netherlands. Observations show, however, that precipitation has on average increased by about $25 \%$ in the last century (Buishand et al., 2013). So apparently factors other than land use changes have been dominant. The observed change in precipitation was larger in the winter half-year than the summer half-year nonetheless, and the trend in the summer months (June-August) in the period 1951-2009 was only about 5\% (Daniels et al., 2014). Hence, land surface changes in the last century might have mitigated some of the precipitation increase in summer and hereby have contributed to the relatively low increase observed in summer. The same seems to happen in the future in the simulations: combining future land use with the expected temperature rise reduces the precipitation increase in the model. This might only hold for summer, however, because historical and theoretical evidence suggests that the precipitation response to land use changes is lower in cases with non-convective precipitation (Pielke et al., 2007; Cotton and Pielke, 2007). Studies for different types of precipitation, taking place in other seasons, are therefore desirable as well.

The climate change scenario used here maintains constant relative humidity in the model. The resulting response in precipitation under current land cover conditions $(\mathrm{REF}+1)$ is close to the expected increase in near surface humidity of about $7 \%$ estimated with the Clausius-Clapeyron equation. It is interesting to note that in all simulations, except for $\mathrm{REF}+1$, no differences in extreme precipitation were simulated. We note that it is not the changes in mean, but the changes in extreme precipitation that may cause problems for society, with for example landslides or urban flooding (e.g., Feddema et al., 2005; Hibbard et al., 2010; Mahmood et al., 2014). In REF+1 precipitation over $15 \mathrm{~mm} \mathrm{~h}^{-1}$ increases with $10 \%$ or more. This increase is higher than the average increase in extreme precipitation simulated by global climate models (GCMs), which is about $6 \%$ per degree global warming (Kharin et al., 2007, 2013). Mean precipitation also increases more in our simulations (7-8\%) than in GCMs $(3 \%)$ (Allen and Ingram, 2002). This can be explained because we investigate hourly data, while GCM data are generally daily, and we only simulate 18 cases, while GCMs generate mean climate simulations. In addition, GCMs generally show a decrease in the occurrence frequency and an increase in the intensity of precipitation. Because we only selected cases in which precipitation occurs, there can be no difference in the occurrence frequency in our simulations. Our estimates are therefore higher than those made by GCMs, but similar to comparable studies (Attema et al., 2014).

\section{Conclusions}

This paper aims to quantify the precipitation response to historic (1900) and future (2040) land use change in the Netherlands, and to put this response in the perspective of climate change. To achieve this, historic, present, and future land use maps are incorporated into the WRF model. In addition, simulations with a temperature perturbation of $+1^{\circ} \mathrm{C}$ are done as a surrogate climate change scenario. The investigation is done for 18 summer days with similar characteristics that were selected with a circulation type classification and $k$-means clustering procedure. On average, precipitation decreases from historic to present land cover by 3-5\%, and decreases by $2-5 \%$ from present to future land cover. Creation of land in Lake Yssel might have caused a decrease in precipitation, but the evidence is not exhaustive. Under the present climate, the simulated land use changes hardly have any influence on extreme precipitation.

Observations of precipitation in the last century show a year-round increase of $25 \%$, but only $5 \%$ in summer. The results in this paper suggest that the relatively low increase in precipitation in summer due to climate change might have been offset by the effects of land use conversion. The same land use-climate compensation occurs in our simulations for 
the future. Precipitation increases by $7-8 \%$ on average in response to the temperature perturbation in the climate simulations and has a disproportional impact on extremes. Expected land use changes, including the expansion of urban areas, diminish this increase, however. As such an average precipitation increase of $2-6 \%$ is achieved in the simulation that combines future land use with climate change. No increase in extreme precipitation is found in the combined future land use-climate change simulation. Overall, although the precipitation response to land use changes is smaller than the response to climate change, it is not negligible in the summer period in the Netherlands. Our simulations suggest this might be especially true for precipitation extremes.

Author contributions. The authors collectively designed the experiments and interpreted the results. Emma Daniels conducted the experiments, analyzed the data, and wrote the paper, which all the authors commented on.

Acknowledgements. Emma Daniels and Geert Lenderink acknowledge contributions of the Knowledge for Climate program, and Ronald Hutjes and Albert Holtslag acknowledge support by the EU EMBRACE program.

Edited by: B. Schaefli

Reviewed by: two anonymous referees

\section{References}

Allen, M. R. and Ingram, W. J.: Constraints on future changes in climate and the hydrologic cycle, Nature, 419, 224-232, doi:10.1038/Nature01092, 2002.

Angel, S., Parent, J., Civco, D. L., Blei, A., and Potere, D.: The dimensions of global urban expansion: Estimates and projections for all countries, 2000-2050, Prog. Plann., 75, 53-107, doi:10.1016/j.progress.2011.04.001, 2011.

Attema, J. J., Loriaux, J. M., and Lenderink, G.: Extreme precipitation response to climate perturbations in an atmospheric mesoscale model, Environ. Res. Lett., 9, 12 pp., doi:10.1088/1748-9326/9/1/014003, 2014.

Buishand, T. A., De Martino, G., Spreeuw, J. N., and Brandsma, T.: Homogeneity of precipitation series in the Netherlands and their trends in the past century, Int. J. Climatol., 33, 815-833, doi:10.1002/joc.3471, 2013.

Core Team R.: R: A language and environment for statistical computing, R Foundation for Statistical Computing, Vienna, Austria, 3501 pp., 2013.

Cotton, W. R. and Pielke, R. A.: Human impacts on weather and climate, Cambridge University Press, 2nd edition edn., 332 pp., 2007.

CPB, MNP, and RPB: Welvaart en Leefomgeving, Een scenariostudie voor Nederland in 2040, Tech. rep., Den Haag, the Netherlands, 2006.
Daniels, E. E., Lenderink, G., Hutjes, R. W. A., and Holtslag, A. A. M.: Spatial precipitation patterns and trends in The Netherlands during 1951-2009, Int. J. Climatol., 34, 1773-1784, doi:10.1002/joc.3800, 2014.

Daniels, E. E., Hutjes, R. W. A., Lenderink, G., Ronda, R. J., and Holtslag, A. A. M.: Land surface feedbacks on spring precipitation in the Netherlands, J. Hydrometeorol., 16, 232-243, doi:10.1175/jhm-d-14-0072.1, 2015a.

Daniels, E. E., Lenderink, G., Hutjes, R. W. A., and Holtslag, A. A. M.: Observed urban effects on precipitation along the Dutch West coast, Int. J. Climatol., 36, 2111-2119, doi:10.1002/joc.4458, 2015b.

Dee, D. P., Uppala, S. M., Simmons, A. J., Berrisford, P., Poli, P., Kobayashi, S., Andrae, U., Balmaseda, M. A., Balsamo, G., Bauer, P., Bechtold, P., Beljaars, A. C. M., van de Berg, L., Bidlot, J., Bormann, N., Delsol, C., Dragani, R., Fuentes, M., Geer, A. J., Haimberger, L., Healy, S. B., Hersbach, H., Hólm, E. V., Isaksen, L., Kållberg, P., Köhler, M., Matricardi, M., McNally, A. P., Monge Sanz, B. M., Morcrette, J. J., Park, B. K., Peubey, C., de Rosnay, P., Tavolato, C., Thépaut, J. N., and Vitart, F.: The ERA-Interim reanalysis: configuration and performance of the data assimilation system, Q. J. Roy. Meteor. Soc., 137, 553-597, doi:10.1002/qj.828, 2011.

Dekkers, J., Koomen, E., Jacobs Crisioni, C., and Rijken, B.: Scenario-based projections of future land use in the Netherlands: A spatially-explicit knowledge base for the Knowledge for Climate programme, Tech. Rep. SL-11, Department of Spatial Economics/ Spatial Information Laboratory (SPINlab), Amsterdam, the Netherlands, 2012.

EEA: Corine land cover 2000, European Environment Agency, available at: http://www.eea.europa.eu/data-and-maps/data/ corine-land-cover-2000-clc2000-seamless-vector-database, 2002.

Feddema, J. J., Oleson, K. W., Bonan, G. B., Mearns, L. O., Buja, L. E., Meehl, G. A., and Washington, W. M.: The importance of land-cover change in simulating future climates, Science, 310, 1674-1678, doi:10.1126/science.1118160, 2005.

Feranec, J., Jaffrain, G., Soukup, T., and Hazeu, G.: Determining changes and flows in European landscapes 1990-2000 using CORINE land cover data, Appl. Geogr., 30, 19-35, doi:10.1016/j.apgeog.2009.07.003, 2010.

Findell, K. L. and Eltahir, E. A. B.: Atmospheric controls on soil moisture-boundary layer interactions: Threedimensional wind effects, J. Geophys. Res.-Atmos., 108 , doi:10.1029/2001jd001515, 2003.

Fischer, E. M., Sedlacek, J., Hawkins, E., and Knutti, R.: Models agree on forced response pattern of precipitation and temperature extremes, Geophys. Res. Lett., 41, 8554-8562, doi:10.1002/2014g1062018, 2014.

Gallus, W. A. and Bresch, J. F.: Comparison of impacts of WRF dynamic core, physics package, and initial conditions on warm season rainfall forecasts, Mon. Weather Rev., 134, 2632-2641, doi:10.1175/mwr3198.1, 2006.

George, J. J.: Weather forecasting for aeronautics, New York and London Academic Press, 673 pp., 1960.

Grell, G.: Prognostic Evaluation of Assumptions Used by $\mathrm{Cu}-$ mulus Parameterizations, Mon. Weather Rev., 121, 764-787, doi:10.1175/1520-0493(1993)121<0764:PEOAUB>2.0.CO;2, 1993. 
Grell, G. and Devenyi, D.: A generalized approach to parameterizing convection combining ensemble and data assimilation techniques, Geophys. Res. Lett., 29, 38-1-38-4, doi:10.1029/2002GL015311, 2002.

Hartigan, J. A. and Wong, M. A.: Algorithm AS 136: A KMeans Clustering Algorithm, J. Roy. Stat. Soc.,, 28, 100-108, doi:10.2307/2346830, 1979.

Hazeu, G., Schuiling, C., Dorland, G., Oldengarm, J., and Gijsbertse, H.: Landelijk grondgebruiksbestand Nederland versie 6 (LGN6); vervaardiging, nauwkeurigheid en gebruik, tech. rep., Alterra, Wageningen, the Netherlands, 2010.

Hazeu, G. W., Bregt, A. K., de Wit, A. J. W., and Clevers, J. G. P. W.: A Dutch multi-date land use database: Identification of real and methodological changes, Int. J. Appl. Earth Obs., 13, 682-689, doi:10.1016/j.jag.2011.04.004, 2011.

Hibbard, K., Janetos, A., van Vuuren, D. P., Pongratz, J., Rose, S. K., Betts, R., Herold, M., and Feddema, J. J.: Research priorities in land use and land-cover change for the Earth system and integrated assessment modelling, Int. J. Climatol., 30, 2118 2128, doi:10.1002/joc.2150, 2010.

Hoeksema, R. J.: Three stages in the history of land reclamation in the Netherlands, Irrig. Drain., 56, S113-S126, doi:10.1002/ird.340, 2007.

Hong, S. and Lim, J. J.: The WRF single-moment 6-class microphysics scheme (WSM6), J. Korean Meteorol. Soc., 42, 129$151,2006$.

Hong, S.-Y., Noh, Y., and Dudhia, J.: A New Vertical Diffusion Package with an Explicit Treatment of Entrainment Processes, Mon. Weather Rev., 134, 2318-2341, doi:10.1175/mwr3199.1, 2006

$\mathrm{Hu}$, X.-M., Nielsen Gammon, J. W., and Zhang, F.: Evaluation of Three Planetary Boundary Layer Schemes in the WRF Model, J. Appl. Meteorol. Climatol., 49, 1831-1844, doi:10.1175/2010jamc2432.1, 2010.

Huntington, T. G.: Evidence for intensification of the global water cycle: Review and synthesis, J. Hydrol., 319, 83-95, doi:10.1016/j.jhydrol.2005.07.003, 2006.

Iacono, M. J., Delamere, J., Mlawer, E., Shephard, M., Clough, S., and Collins, W.: Radiative forcing by long-lived greenhouse gases: Calculations with the AER radiative transfer models, J. Geophys. Res., 113, 8 pp., doi:10.1029/2008JD009944, 2008.

IPCC: Climate Change 2013: The Physical Science Basis. Contribution of Working Group I to the Fifth Assessment Report of the Intergovernmental Panel on Climate Change, Tech. rep., Cambridge, UK and New York, NY, USA, doi:10.1017/CBO9781107415324, 2013.

Jankov, I., Gallus, W. A., Segal, M., Shaw, B., and Koch, S. E.: The impact of different WRF model physical parameterizations and their interactions on warm season MCS rainfall, Weather Forecast., 20, 1048-1060, doi:10.1175/waf888.1, 2005.

Jenkinson, A. and Collison, B.: An Initial Climatology of Gales Over the North Sea, Tech. Rep. Memorandium No. 62, Meteorological Institution, London, UK, 1977.

Jones, P. D., Hulme, M., and Briffa, K. R.: A comparison of lamb circulation types with an objective classification scheme, Int. J. Climatol., 13, 655-663, doi:10.1002/joc.3370130606, 1993.

Kalnay, E. and Cai, M.: Impact of urbanization and land-use change on climate, Nature, 423, 528-531, doi:10.1038/nature01675, 2003.
Kharin, V. V., Zwiers, F. W., Zhang, X., and Hegerl, G. C.: Changes in Temperature and Precipitation Extremes in the IPCC Ensemble of Global Coupled Model Simulations, J. Climate, 20, 1419 1444, doi:10.1175/jcli4066.1, 2007.

Kharin, V. V., Zwiers, F. W., Zhang, X., and Wehner, M.: Changes in temperature and precipitation extremes in the CMIP5 ensemble, Clim. Change, 119, 345-357, doi:10.1007/s10584-013-0705-8, 2013.

Kramer, H., Dorland, G. V., and Gijsbertse, H.: Historisch grondgebruik Nederland, in: Tijd en Ruimte. Nieuwe toepassingen van GIS in de alfawetenschappen, edited by: Boonstra, O. and Schuurman, A., 142-153, Uitgeverij Matrijs, Utrecht, the Netherlands, 2010.

Kusaka, H. and Kimura, F.: Thermal effects of urban canyon structure on the nocturnal heat island: Numerical experiment using a mesoscale model coupled with an urban canopy model, J. Appl Meteorol., 43, 1899-1910, doi:10.1175/jam2169.1, 2004.

Kusaka, H., Kondo, H., Kikegawa, Y., and Kimura, F.: A Simple Single-Layer Urban Canopy Model For Atmospheric Models: Comparison With Multi-Layer And Slab Models, Bound.-Lay. Meteorol., 101, 329-358, doi:10.1023/a:1019207923078, 2001.

Lamb, H.: Types and spells of weather around the year in the British Isles: annual trends, seasonal structure of years, singularities, Q. J. Roy. Meteor. Soc., 76, 393-438, 1950.

Lenderink, G., van Meijgaard, E., and Selten, F.: Intense coastal rainfall in the Netherlands in response to high sea surface temperatures: analysis of the event of August 2006 from the perspective of a changing climate, Clim. Dynam., 32, 19-33, doi:10.1007/s00382-008-0366-x, 2009.

Loriaux, J. M., Lenderink, G., De Roode, S. R., and Siebesma, A. P.: Understanding Convective Extreme Precipitation Scaling Using Observations and an Entraining Plume Model, J. Atmos. Sci., 70, 3641-3655, doi:10.1175/jas-d-12-0317.1, 2013.

Mahmood, R., Pielke, R. A., Hubbard, K. G., Niyogi, D., Bonan, G., Lawrence, P., McNider, R., McAlpine, C., Etter, A., Gameda, S., Qian, B. D., Carleton, A., Beltran Przekurat, A., Chase, T., Quintanar, A. I., Adegoke, J. O., Vezhapparambu, S., Conner, G., Asefi, S., Sertel, E., Legates, D. R., Wu, Y. L., Hale, R., Frauenfeld, O. W., Watts, A., Shepherd, M., Mitra, C., Anantharaj, V. G., Fall, S., Lund, R., Trevino, A., Blanken, P., Du, J. Y., Chang, H. I., Leeper, R. E., Nair, U. S., Dobler, S., Deo, R., and Syktus, J.: Impacts of land use/land cover change on climate and future research priorities, B. Am. Meteor. Soc., 91, 37-46, doi:10.1175/2009bams2769.1, 2010.

Mahmood, R., Pielke, R. A., Hubbard, K. G., Niyogi, D., Dirmeyer, P. A., McAlpine, C., Carleton, A. M., Hale, R., Gameda, S., Beltran Przekurat, A., Baker, B., McNider, R., Legates, D. R., Shepherd, M., Du, J. Y., Blanken, P. D., Frauenfeld, O. W., Nair, U. S., and Fall, S.: Land cover changes and their biogeophysical effects on climate, Int. J. Climatol., 34, 929-953, doi:10.1002/joc.3736, 2014.

Mahoney, K., Alexander, M. A., Thompson, G., Barsugli, J. J., and Scott, J. D.: Changes in hail and flood risk in high-resolution simulations over Colorado's mountains, Nature Clim. Change, 2, 125-131, 2012.

Marshall, J. D.: Urban Land Area and Population Growth: A New Scaling Relationship for Metropolitan Expansion, Urban Stud., 44, 1889-1904, doi:10.1080/00420980701471943, 2007. 
Overeem, A., Holleman, I., and Buishand, T.: Derivation of a 10year radar-based climatology of rainfall, J. Appl. Meteorol. Climatol., 48, 1448-1463, doi:10.1175/2009JAMC1954.1, 2009.

O'Gorman, P. and Muller, C. J.: How closely do changes in surface and column water vapor follow Clausius-Clapeyron scaling in climate change simulations?, Environ. Res. Lett., 5, 025207, doi:10.1088/1748-9326/5/2/025207, 2010.

Philipp, A., Bartholy, J., Beck, C., Erpicum, M., Esteban, P., Fettweis, X., Huth, R., James, P., Jourdain, S., Kreienkamp, F., Krennert, T., Lykoudis, S., Michalides, S. C., Pianko Kluczynska, K., Post, P., Rasilla Alvarez, D., Schiemann, R., Spekat, A., and Tymvios, F. S.: Cost733cat-A database of weather and circulation type classifications, Phys. Chem. Earth, 35, 360-373, doi:10.1016/j.pce.2009.12.010, 2010.

Philipp, A., Beck, C., Huth, R., and Jacobeit, J.: Development and comparison of circulation type classifications using the COST 733 dataset and software, Int. J. Climatol., 36, 2673-2691, doi:10.1002/joc.3920, 2014.

Pielke, R. A., Adegoke, J. O., Chase, T. N., Marshall, C. H., Matsui, T., and Niyogi, D.: A new paradigm for assessing the role of agriculture in the climate system and in climate change, Agr. Forest Meteorol., 142, 234-254, doi:10.1016/j.agrformet.2006.06.012, 2007.

Pineda, N., Jorba, O., Jorge, J., and Baldasano, J. M.: Using NOAA AVHRR and SPOT VGT data to estimate surface parameters: application to a mesoscale meteorological model, Int. J. Remote Sens., 25, 129-143, doi:10.1080/0143116031000115201, 2004.

Rajeevan, M., Kesarkar, A., Thampi, S. B., Rao, T. N., Radhakrishna, B., and Rajasekhar, M.: Sensitivity of WRF cloud microphysics to simulations of a severe thunderstorm event over Southeast India, Ann. Geophys., 28, 603-619, doi:10.5194/angeo-28603-2010, 2010.

Ruiz, J. J., Saulo, C., and Nogues Paegle, J.: WRF Model Sensitivity to Choice of Parameterization over South America: Validation against Surface Variables, Mon. Weather Rev., 138, 3342-3355, doi:10.1175/2010mwr3358.1, 2010.

Santanello, J. A., Peters Lidard, C. D., and Kumar, S. V.: Diagnosing the Sensitivity of Local Land-Atmosphere Coupling via the Soil Moisture-Boundary Layer Interaction, J. Hydrometeorol., 12, 766-786, doi:10.1175/jhm-d-10-05014.1, 2011.

Schar, C., Frei, C., Luthi, D., and Davies, H. C.: Surrogate climatechange scenarios for regional climate models, Geophys. Res. Lett., 23, 669-672, doi:10.1029/96g100265, 1996.

Seneviratne, S. I., Luthi, D., Litschi, M., and Schar, C.: Landatmosphere coupling and climate change in Europe, Nature, 443, 205-209, doi:10.1038/nature05095, 2006.

Skamarock, W., Klemp, J., Dudhia, J., Gill, D., Barker, D., Duda, M., Huang, X., Wang, W., and Powers, J.: A Description of the Advanced Research WRF Version 3, Tech. rep., National Center for Atmospheric Research, Boulder, Colorado, USA, 2008.

Steeneveld, G. J., Tolk, L. F., Moene, A. F., Hartogensis, O. K., Peters, W., and Holtslag, A. A. M.: Confronting the WRF and RAMS mesoscale models with innovative observations in the Netherlands: Evaluating the boundary layer heat budget, J. Geophys. Res.-Atmos., 116, 16 pp., doi:10.1029/2011jd016303, 2011.

Taylor, C. M., de Jeu, R. A. M., Guichard, F., Harris, P. P., and Dorigo, W. A.: Afternoon rain more likely over drier soils, Nature, 489, 423-426, doi:10.1038/nature11377, 2012. ter Maat, H. W., Moors, E. J., Hutjes, R. W. A., Holtslag, A. A. M., and Dolman, A. J.: Exploring the Impact of Land Cover and Topography on Rainfall Maxima in the Netherlands, J. Hydrometeorol., 14, 524-542, doi:10.1175/jhm-d-12-036.1, 2013.

Tewari, M., Chen, F., Wang, W., Dudhia, J., LeMone, M., Mitchell, K., Ek, M., Gayno, G., Wegiel, J., and Cuenca, R.: Implementation and verification of the unified NOAH land surface model in the WRF model, in: 20th conference on weather analysis and forecasting/16th conference on numerical weather prediction, 11-15, 2004.

The GLACE Team, Koster, R. D., Dirmeyer, P. A., Guo, Z., Bonan, G., Chan, E., Cox, P., Gordon, C. T., Kanae, S., Kowalczyk, E., Lawrence, D., Liu, P., Lu, C.-H., Malyshev, S., McAvaney, B., Mitchell, K., Mocko, D., Oki, T., Oleson, K., Pitman, A., Sud, Y. C., Taylor, C. M., Verseghy, D., Vasic, R., Xue, Y., and Yamada, T.: Regions of Strong Coupling Between Soil Moisture and Precipitation, Science, 305, 1138-1140, doi:10.1126/science.1100217, 2004.

Theeuwes, N. E., Solcerová, A., and Steeneveld, G. J.: Modeling the influence of open water surfaces on the summertime temperature and thermal comfort in the city, J. Geophys. Res.-Atmos., 118, 8881-8896, doi:10.1002/jgrd.50704, 2013.

Trusilova, K., Jung, M., Churkina, G., Karstens, U., Heimann, M., and Claussen, M.: Urbanization Impacts on the Climate in Europe: Numerical Experiments by the PSU-NCAR Mesoscale Model (MM5), J. Appl. Meteorol. Climatol., 47, 1442-1455, doi:10.1175/2007jamc1624.1, 2008.

Trusilova, K., Jung, M., and Churkina, G.: On Climate Impacts of a Potential Expansion of Urban Land in Europe, J. Appl. Meteorol Climatol., 48, 1971-1980, doi:10.1175/2009jamc2108.1, 2009.

van Haren, R., Oldenborgh, G., Lenderink, G., Collins, M., and Hazeleger, W.: SST and circulation trend biases cause an underestimation of European precipitation trends, Clim. Dynam., 40, 1-20, doi:10.1007/s00382-012-1401-5, 2013.

Verburg, P. H., van Eck, J. R. R., de Nijs, T. C. M., Dijst, M. J., and Schot, P.: Determinants of land-use change patterns in the Netherlands, Environ. Plann. B, 31, 125-150, doi:10.1068/b307, 2004.

Wit, A. J. W. D.: Land use mapping and monitoring in the Netherlands using remote sensing data, in: IEEE international geoscience and remote sensing symposium, Learning from Earth's shapes \& colors, Toulouse, 3 pp., 2003.

Wu, P., Christidis, N., and Stott, P.: Anthropogenic impact on Earth's hydrological cycle, Nature Clim. Change, 3, 807-810, doi:10.1038/nclimate1932, 2013.

Zeng, X. M., Wu, Z. H., Song, S., Xiong, S. Y., Zheng, Y. Q., Zhou, Z. G., and Liu, H. Q.: Effects of land surface schemes on the simulation of a heavy rainfall event by WRF, Chinese J. Geophys., 55, 16-28, doi:10.6038/j.issn.0001-5733.2012.01.002, 2012.

Zhang, X., Zwiers, F. W., Hegerl, G. C., Lambert, F. H., Gillett, N. P., Solomon, S., Stott, P. A., and Nozawa, T.: Detection of human influence on twentieth-century precipitation trends, Nature, 448, 461-465, 2007. 